\title{
Effect of Inclusion of Rice DDGS on the Performance in Crossbred Pigs
}

\author{
A. V. Siva Reddy*, MVAN. Suryanarayana, A. Ravi, \\ G. Ganga Raju and D. Suresh Babu \\ MVSC (Animal Nutrition) College of Veterinary Science, \\ Tirupati - 517502, Andhra Pradesh, India \\ *Corresponding author
}

\section{A B S T R A C T}

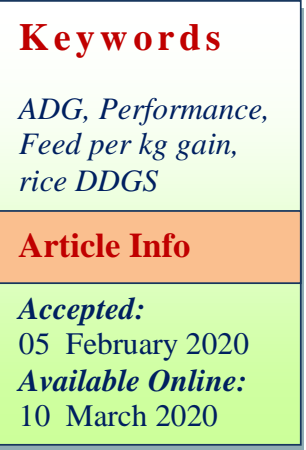

\begin{abstract}
Four dietary treatments were evaluated for their effect on growth performance of crossbred (LWY x Desi) male pigs during grower and finisher phases in a Completely Randomized Block Design. A Basal ration $(\mathrm{T} 1)+100 \mathrm{~g}$ of Probiotic $($ Bacillus $)+500 \mathrm{~g}$ of enzyme cocktail per ton of feed, $\mathrm{T} 1+$ DDGS to contribute $20 \%$ of the total protein $(9 \% \& 7.5 \%$ of diet during grower and finisher phases, respectively (T2); T1 + DDGS to contribute $30 \%$ of the total protein $(12.5 \%$ \& $11 \%$ of diets during grower and finisher phases, respectively(T3); T1 + DDGS to contribute $40 \%$ of the total protein $(16.5 \% \& 15 \%$ of diets during grower and finisher phases, respectively(T4). During grower phase, the pigs fed $\mathrm{T} 1$ have taken less $(\mathrm{P}<0.05)$ number of days than those fed T4. ADG $(\mathrm{g})$ was higher $(\mathrm{P}<0.05)$ in $\mathrm{T} 1(440)$ or $\mathrm{T} 2$ (432) fed pigs than in T3 (413) and T4 (382) fed pigs and during finisher phase, initial, final and total weight gain $(\mathrm{kg})$ were not significantly different among treatments. Number of days taken was T1 (90), T2 (92), T3 (88), T4 (96) and were not significant. ADG (g) in $\mathrm{T} 1$ to $\mathrm{T} 4$ diets fed pigs was 400, 392, 405 and 370, respectively. The ADFI (kg), the feed per $\mathrm{kg}$ gain and the cost of feed per kg gain (Rs) were not significantly different among treatments. During overall growth performance, ADG $(\mathrm{g})$ was higher $(\mathrm{P}<0.05)$ in $\mathrm{T} 1(423)$ followed by T2 $(412), \mathrm{T} 3$ (409) and lowest in T4 (372) fed pigs. The ADFI ( $\mathrm{kg}$ ) and the feed per kg gain were not significantly different among treatments. The cost of feed per kg gain $(\mathrm{Rs})$ was higher $(\mathrm{P}<0.05)$ in $\mathrm{T} 1(98.8)$ or $\mathrm{T} 2$ (93.8) fed pigs than in T3 (92.2) and T4 (84.3) fed pigs. It was concluded that contributing (\%) 20 and 30 of the CP through DDGS improved ADG and reduced the cost of feed gain per $\mathrm{kg}$ gain in growers and finishers, respectively.
\end{abstract}

\section{Introduction}

Pig as compared to other livestock species has a great potential to contribute to faster economic return to the farmers, because of certain inherent traits like high fecundity, better-feed conversion efficiency, early maturity and short generation interval. The dressing percentage is also higher (Jaishankar et al., 2015). Over decades, Corn and Soybean have been the major components of conventional feed for pigs and satisfy the needs for energy and protein. But owing to an increased cost of production, use of other non-edible human protein and energy sources have come into picture

Distillers dried grains with solubles (DDGS) is a by-product of the beverage and fuel alcohol industries (Stein and De Lange, 2007). It has a relatively high concentration of energy and digestible phosphorus, and a 
moderate concentration of protein and it can partially replace The relatively high abundance, low price, and high nutritional value of DDGS make it a popular costeffective alternative feed ingredient for swine producers. Including DDGS in swine diets concurrently minimized cost of production (De Matteisa et al., 2018).

DDGS product obtained from Rice Distillery is called Rice Distillers Dried Grains with Solubles (RDDGS). India is one of the largest producers of rice in world producing approximately 111.52 MT of rice in 2017-18 (IBEF, 2018). It is a good source of phosphorus and maximum of it is present as non phytate form which is readily available to animal.

Rice-based DDG has been reported to have higher contents of protein $(47.5 \%)$ and fiber (15.8\%) (Chatterjee et al., 2016) when compared with those of corn-based DDGS (Liu, 2011).Hence the present work was planned by including the Rice DDGS in the pig diets to study the productive performance.

\section{Materials and Methods}

In a Completely Randomized Design four dietary treatments were evaluated for their effect on growth performance of crossbred (LWY x Desi) male pigs during grower and finisher phases. Four isonitrogenous experimental diets were formulated as per NRC (2012) and fed during grower (15 -35 kg body weight) and finisher $(35-70 \mathrm{~kg}$ body weight) phases. The dietary treatments were as shown below:

Control diet (T1) - Basal ration $+100 \mathrm{~g}$ of Probiotic (Bacillus) $+500 \mathrm{~g}$ of enzyme cocktail per ton of feed.

Experimental diet 2 (T2) - T1 + DDGS to contribute $20 \%$ of the total protein $(9 \%$ \&
$7.5 \%$ of diet during grower and finisher phases, respectively)

Experimental diet 3 (T3) - T1 + DDGS to contribute $30 \%$ of the total protein $(12.5 \%$ \& $11 \%$ of diet during grower and finisher phases, respectively)

Experimental diet 4 (T4) - T1 + DDGS to contribute $40 \%$ of the total protein $(16.5 \%$ of $\& 15 \%$ of diet during grower and finisher phases, respectively).

The experiment was carried out on 24 crossbred (Large White Yorkshire) male pigs and distributed randomly into four groups with six animals in each group. Dietary treatments consisted of corn, soybean meal control (T1) or Rice Distillers Dried Grain Solubles to contribute 20 (T2), 30(T3) and $40 \%$ (T4) of the total protein of $\mathrm{T} 1$. At the beginning of experiment, animals were weighed for two consecutive days in the morning before feeding and watering.

Then animals were weighed individually at 14 days interval during experimental period before feeding and watering to record the body weight change. The chemical composition of Maize, Soybean meal, Rice DDGS and De-oiled rice bran used in the experimental diets is- the percent $\mathrm{DM}, \mathrm{CP}$, EE, CF, TA, NFE, NDF, ADF and Hemi cellulose were 88.9, 10.6, 4.1, 2.7, 6.9, 75.7, 14.5, 9.7 and 4.8 (Maize); 90.9, 42.9, 1.0, 7.2, 10.0, 40.0, 39.7, 22.4 and 17.3 (Soybean meal); 88.5, 39.0, 2.3, 11.2, 6.5, 41.3, 37.0, 22.0 and 15.0 (Rice DDGS) and 88.9, 15, 1.5, 17.8, 15.9, 51.8, 47.2, 34.3 and 12.9 (De-oiled rice bran ), respectively.

The ingredient and chemical composition (\%) of the experimental grower and finisher diets fed to pigs from 15 to $35 \mathrm{~kg}$ and $35 \mathrm{~kg}$ to 70 $\mathrm{kg}$ body weight are presented in Tables $1 \& 2$, respectively. Synerzyme-P-FS (a combination 
of Amylase, Hemi-cellulase, Xylanase, Galactosidase, Cellulase, Protease, $\beta$-glucanse and Phytase) as Enzyme cocktail and Bacillus probiotic added uniformly to T1, T2, T3, and $\mathrm{T} 4$ @ 50g and $10 \mathrm{~g} / 100 \mathrm{~kg}$ of feed respectively.

\section{Results and Discussion}

The growth performance of the pigs fed during grower phase is presented in Table 3. The initial and final weights $(\mathrm{kg})$ were not significantly different among treatments. Similarly the weight gain $(\mathrm{kg})$ was also not significantly different among treatments and the pigs fed $\mathrm{T} 1$ have taken less $(\mathrm{P}<0.05)$ number of days (Fig.2) than those fed T4. ADG (g) was higher $(\mathrm{P}<0.05)$ in $\mathrm{T} 1(440)$ or T2 (432) fed pigs than (Fig.1) in T3 (413) and T4 (382) fed pigs. The ADFI $(\mathrm{kg})$ and the feed per kg gain (Fig.3) were not significantly different among treatments.

The cost of feed per $\mathrm{kg}$ gain (Rs) was significantly $(\mathrm{P}<0.05)$ higher in $\mathrm{T} 1$ than in other treatments. During finisher phase, initial, final and total weightgain $(\mathrm{kg})$ were not (Table 4) significantly different among treatments. Number of days taken was T1 (90), T2 (92), T3 (88), T4 (96) and were not significant. ADG (g) in T1 to T4 diets (Fig.4) fed pigs was 400, 392, 405 and 370, respectively. The ADFI $(\mathrm{kg})$, the feed per $\mathrm{kg}$ gain (Fig.5) and the cost of feed (Fig.6) per kg gain (Rs) were not significantly different among treatments

During overall growth performance, (15-70 $\mathrm{kg})$.initial and final weights $(\mathrm{kg})$, weight gain $(\mathrm{kg})$ and (Table 5) the number of days taken to reach the target weight were comparable among treatments. However, the ADG (g) was higher $(\mathrm{P}<0.05)$ in $\mathrm{T} 1 \quad(423)$ followed by T2 (412), T3 (409) and lowest in T4 (372) fed pigs. The ADFI (kg) and the feed per $\mathrm{kg}$ gain were not significantly different among treatments and the values were 1.80 and 4.3 for T1, 1.78 and 4.4 for T2, 1.80 and 4.4 for $\mathrm{T} 3$ and 1.73 and 4.7 for T4 fed pigs. The cost of feed per $\mathrm{kg}$ gain $(\mathrm{Rs})$ was higher $(\mathrm{P}<0.05)$ in T1 (98.8) or T2 (93.8) fed pigs than in T3 (92.2) and T4 (84.3) fed pigs.

As seen from the table it is evident that the initial and final weight showed similar values and was non- significant. The number of days taken to achieve the target weight increased $(\mathrm{P}<0.05)$ from $\mathrm{T} 1$ to $\mathrm{T} 4$ with a corresponding decrease in ADG $(\mathrm{g})$ and ADFI $(\mathrm{kg})$.

The results of present study were partially in agreement with previous studies of Thacker (2006), Feoli (2008), Linneen et al., (2008) where they have observed growth inhibition when either nursery or growing-finishing pigs were fed diets containing of up $30 \%$ of corn, wheat or sorghum DDGS. Results from some studies have shown that feeding diets containing 20 or $30 \%$ DDGS can did not affect growth performance (Cook et al., 2005; DeDecker et al., 2005; Gaines et al., 2007), whereas other studies (Whitney et al., 2006; Linneen et al., 2008) have shown a negative effect on ADG and ADFI when pigs were fed diets containing DDGS levels $20 \%$ and above as compared with control diet (corn-soybean meal diets).

It was reported that DDGS contains a higher digestible energy and AA content than cereal grain from which it was prepared (Widyaratne and Zijlstra, 2007), but following precharacterization and incorporation of the digestible nutrient content information in diet formulation, DDGS caused a reduction in voluntary feed intake, ADG and final body weight. The same trend would have been implied in present study also. The other reason for a reduced ADFI could be attributed to an increase in the dietary inclusion levels of DDGS would have affected the palatability negatively (Whitney et al., 2006). 
During overall growth performance, the total weight gain was not significant among treatments. Whereas there was a distinct increase in number of days taken to reach target weight due to rice DDGS inclusion, which was more pronounced in T4. However, the feed per $\mathrm{kg}$ gain was not significantly different across treatments. On the positive side, there was a decrease in feed cost $/ \mathrm{kg}$ gain by Rs.5.0, 6.6 and 14.5 in T2, T3 and T4 fed pigs than in $\mathrm{T} 1$ fed pigs, which was significantly different $(\mathrm{P}<0.05)$.

Table.1 Ingredient and chemical composition (\%) of experimental grower diets

\begin{tabular}{|c|c|c|c|c|}
\hline Ingredient & T1 & T2 & T3 & T4 \\
\hline Maize & 60 & 59 & 59 & 59 \\
\hline Soybean meal & 20 & 12 & 9.5 & 5.5 \\
\hline Rice DDGS & - & 9 & 12.5 & 16.5 \\
\hline Deioled Rice bran & 18 & 18 & 17 & 17 \\
\hline Mineral mixture \# & 1.5 & 1.5 & 1.5 & 1.5 \\
\hline \multirow[t]{2}{*}{ Salt } & 0.5 & 0.5 & 0.5 & 0.5 \\
\hline & 100 & 100 & 100 & 100 \\
\hline Lysine (\%) & 0.47 & 0.63 & 0.70 & 0.81 \\
\hline Methionine (\%) & 0.05 & 0.05 & 0.05 & 0.05 \\
\hline Bacillus (gm/100kg) & 10 & 10 & 10 & 10 \\
\hline Multi enzyme(gm/100kg) & 50 & 50 & 50 & 50 \\
\hline Cost per 100kg (Rs.) & 2355 & 2238 & 2209 & 2154 \\
\hline \multicolumn{5}{|l|}{ Proximate composition $(\%)^{a}$} \\
\hline DM & 91 & 91.2 & 91.1 & 91.1 \\
\hline OM & 89.1 & 89.5 & 89.4 & 89.5 \\
\hline $\mathbf{C P}$ & 16.4 & 16.2 & 16.1 & 16.4 \\
\hline TA & 10.9 & 10.5 & 10.6 & 10.5 \\
\hline $\mathbf{E E}$ & 1.7 & 1.9 & 1.8 & 1.8 \\
\hline $\mathbf{C F}$ & 9.2 & 9.6 & 9.9 & 10.7 \\
\hline NFE & 61.8 & 61.8 & 61.6 & 60.6 \\
\hline Calcium & 0.67 & 0.62 & 0.66 & 0.70 \\
\hline Phosphorus & 0.30 & 0.30 & 0.31 & 0.32 \\
\hline GE (kcal/g) & 3591 & 3747 & 3856 & 3919 \\
\hline \multicolumn{5}{|l|}{ Cell wall composition $(\%)^{a}$} \\
\hline NDF & 27.53 & 28.60 & 28.80 & 29.20 \\
\hline ADF & 17.10 & 17.30 & 17.60 & 18.10 \\
\hline Hemicellulose & 10.43 & 11.30 & 11.20 & 11.10 \\
\hline
\end{tabular}


Table.2 Ingredient and chemical composition (\%) of experimental finisher diets

\begin{tabular}{|c|c|c|c|c|}
\hline Ingredient & T1 & T2 & T3 & T4 \\
\hline Maize & 59 & 59 & 59 & 59 \\
\hline Soybean meal & 15 & 9 & 6 & 2 \\
\hline Rice DDGS & - & 7.5 & 11 & 15 \\
\hline Deioled Rice bran & 24 & 22.5 & 22 & 22 \\
\hline Mineral mixture \# & 1.5 & 1.5 & 1.5 & 1.5 \\
\hline \multirow[t]{2}{*}{ Salt } & 0.5 & 0.5 & 0.5 & 0.5 \\
\hline & 100 & 100 & 100 & 100 \\
\hline Lysine (\%) & 0.41 & 0.57 & 0.65 & 0.76 \\
\hline Methionine (\%) & 0.04 & 0.04 & 0.04 & 0.04 \\
\hline Bacillus (gm/100kg) & 10 & 10 & 10 & 10 \\
\hline Multi enzyme(gm/100kg) & 50 & 50 & 50 & 50 \\
\hline Cost per 100kg (Rs.) & 2205 & 2133 & 2094 & 1939 \\
\hline \multicolumn{5}{|l|}{ Proximate composition (\%) } \\
\hline DM & 91.6 & 92 & 91.5 & 91.3 \\
\hline $\mathbf{O M}$ & 88.2 & 88.9 & 89.2 & 89.2 \\
\hline $\mathbf{C P}$ & 14.5 & 14.3 & 14.4 & 14.2 \\
\hline TA & 11.8 & 11.1 & 10.8 & 10.8 \\
\hline $\mathbf{E E}$ & 1.7 & 1.6 & 1.9 & 1.6 \\
\hline $\mathbf{C F}$ & 14.5 & 14.8 & 15.2 & 15.9 \\
\hline NFE & 57.5 & 58.2 & 57.7 & 57.5 \\
\hline Calcium & 0.73 & 0.69 & 0.72 & 0.69 \\
\hline Phosphorus & 0.31 & 0.32 & 0.31 & 0.35 \\
\hline GE (kcal/g) & 3500 & 3625 & 3714 & 3792 \\
\hline \multicolumn{5}{|l|}{ Cell wall composition (\%) } \\
\hline NDF & 29.7 & 30.1 & 30.4 & 30.5 \\
\hline ADF & 19.4 & 19.1 & 19.0 & 19.2 \\
\hline Hemicellulose & 10.30 & 11.00 & 11.40 & 11.30 \\
\hline
\end{tabular}

${ }^{\mathrm{a}}$ on Dry Matter basis except for DM

\# per kg contained - Ca 25.5\%; P 12.75\%; S 0.72\%; Zn 9600mg; Mn 1500mg; Na 5.9mg; K 100 mg; Mg 6000mg; Fe 1500mg; Iodine325mg; Cu 12000mg; Co $150 \mathrm{mg}$ 
Table.3 Growth performance of growers

\begin{tabular}{|l|c|c|c|c|c|}
\hline \multicolumn{1}{|c|}{ Parameter } & T1 & T2 & T3 & T4 & P-value \\
\hline Initial wt. (kg) & $15.21 \pm 0.21$ & $15.35 \pm 0.34$ & $15.23 \pm 0.23$ & $15.18 \pm 0.07$ & 0.968 \\
\hline Final wt. (kg) & $35.65 \pm 0.17$ & $35.08 \pm 0.24$ & $35.32 \pm 0.23$ & $35.23 \pm 0.23$ & 1.000 \\
\hline Weight gain (kg) & $20.43 \pm 0.22$ & $19.73 \pm 0.36$ & $20.08 \pm 0.25$ & $20.05 \pm 0.22$ & 0.815 \\
\hline No. of days* & $45.51^{\mathrm{a}} \pm 2.21$ & $46.2^{\mathrm{a}} \pm 3.06$ & $48.8^{\mathrm{ab}} \pm 1.81$ & $52.7^{\mathrm{b}} \pm 0.83$ & 0.039 \\
\hline ADG (g)* & $440^{\mathrm{b}} \pm 16$ & $432^{\mathrm{b}} \pm 19$ & $413^{\mathrm{ab}} \pm 10$ & $382^{\mathrm{a}} \pm 9$ & 0.047 \\
\hline ADFI (kg) & $1.4 \pm 0.05$ & $1.3 \pm 0.05$ & $1.3 \pm 0.03$ & $1.12 \pm 0.01$ & 0.105 \\
\hline Feed /kg gain & $3.2 \pm 0.11$ & $3.0 \pm 0.23$ & $3.2 \pm 0.18$ & $3.4 \pm 0.14$ & 0.563 \\
\hline $\begin{array}{l}\text { Cost of feed/kg } \\
\text { gain (Rs)* }\end{array}$ & $75.9 \pm 3.05^{\mathrm{b}}$ & $64.3 \pm 3.32^{\mathrm{a}}$ & $64.7 \pm 3.10^{\mathrm{a}}$ & $66.7 \pm 2.43^{\mathrm{a}}$ & 0.043 \\
\hline $\begin{array}{l}\text { abc } \\
\text { **alues in a row not sharing common superscripts differ significantly }\end{array}$ (P.01) $^{(\mathbf{P}<\mathbf{0 . 0 5 )}}$ \\
\hline
\end{tabular}

Table.4 Growth performance of finishers

\begin{tabular}{|c|c|c|c|c|c|}
\hline Parameter & T1 & T2 & T3 & T4 & P- value \\
\hline Initial wt. (kg) & $35.65 \pm 0.17$ & $35.08 \pm 0.24$ & $35.32 \pm 0.23$ & $35.23 \pm 0.23$ & 1.000 \\
\hline Final wt. (kg) & $70.4 \pm 0.17$ & $70.3 \pm 0.24$ & $70.4 \pm 0.23$ & $70.2 \pm 0.23$ & 0.469 \\
\hline Weight gain (kg) & $35.2 \pm 0.22$ & $35.3 \pm 0.36$ & $35.2 \pm 0.25$ & $35.0 \pm 0.22$ & 0.893 \\
\hline No. of days & $89.5 \pm 2.21$ & $92.3 \pm 3.06$ & $87.7 \pm 1.81$ & $95.8 \pm 0.83$ & 0.736 \\
\hline ADG (g) & $400 \pm 16$ & $392 \pm 19$ & $405 \pm 10$ & $370 \pm 91$ & 0.776 \\
\hline ADFI (kg) & $2.2 \pm 0.05$ & $2.3 \pm 0.05$ & $2.3 \pm 0.03$ & $2.1 \pm 0.01$ & 0.090 \\
\hline Feed /kg gain & $5.6 \pm 0.11$ & $5.9 \pm 0.23$ & $5.7 \pm 0.18$ & $5.9 \pm 0.14$ & 0.812 \\
\hline $\begin{array}{c}\text { Cost of feed /kg } \\
\text { gain (Rs) }\end{array}$ & $123 \pm 5.98$ & $118.2 \pm 6.7$ & $112.7 \pm 5.9$ & $113.3 \pm 6.01$ & 0.613 \\
\hline
\end{tabular}

Table.5 Overall growth performance

\begin{tabular}{|c|c|c|c|c|c|}
\hline Parameter & T1 & T2 & T3 & T4 & P- value \\
\hline Initial wt. (kg) & $15.21 \pm 0.21$ & $15.35 \pm 0.34$ & $15.23 \pm 0.23$ & $15.18 \pm 0.07$ & 0.968 \\
\hline Final wt. (kg) & $70.4 \pm 0.17$ & $70.3 \pm 0.24$ & $70.4 \pm 0.23$ & $70.2 \pm 0.23$ & 0.469 \\
\hline Weight gain (kg) & $55.08 \pm 0.56$ & $54.91 \pm 0.56$ & $55.11 \pm 0.45$ & $54.9 \pm 0.84$ & 0.915 \\
\hline No. of days & $134.7 \pm 1.12$ & $138.5 \pm 0.95$ & $136.7 \pm 0.95$ & $148.5 \pm 1.54$ & 0.366 \\
\hline ADG (g)* & $423^{\mathrm{b}} \pm 15.09$ & $412^{\mathrm{ab}} \pm 7.16$ & $409^{\mathrm{ab}} \pm 7.76$ & $372^{\mathrm{a}} \pm 12.75$ & 0.048 \\
\hline ADFI (kg) & $1.80 \pm 0.008$ & $1.78 \pm 0.002$ & $1.80 \pm 0.014$ & $1.73 \pm 0.023$ & 0.126 \\
\hline Feed /kg gain & $4.3 \pm 0.008$ & $4.4 \pm 0.11$ & $4.4 \pm 5.69$ & $4.7 \pm 0.18$ & 0.280 \\
\hline $\begin{array}{c}\text { Cost of feed /kg } \\
\text { gain(Rs) }\end{array}$ & $98.8 \pm 4.04^{\mathrm{b}}$ & $93.8 \pm 3.09^{\mathrm{b}}$ & $92.2 \pm 2.02^{\mathrm{ab}}$ & $84.3 \pm 2.45^{\mathrm{a}}$ & 0.020 \\
\hline
\end{tabular}


Int.J.Curr.Microbiol.App.Sci (2020) 9(3): 418-428

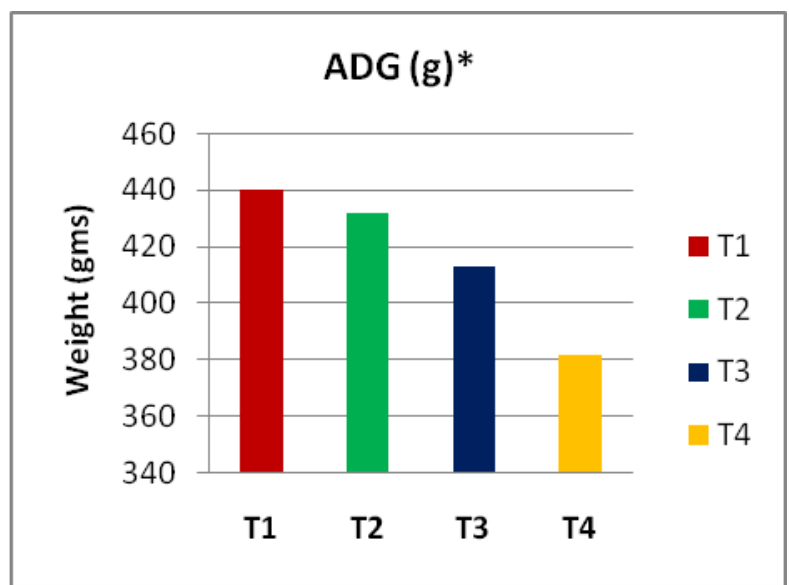

Fig.1

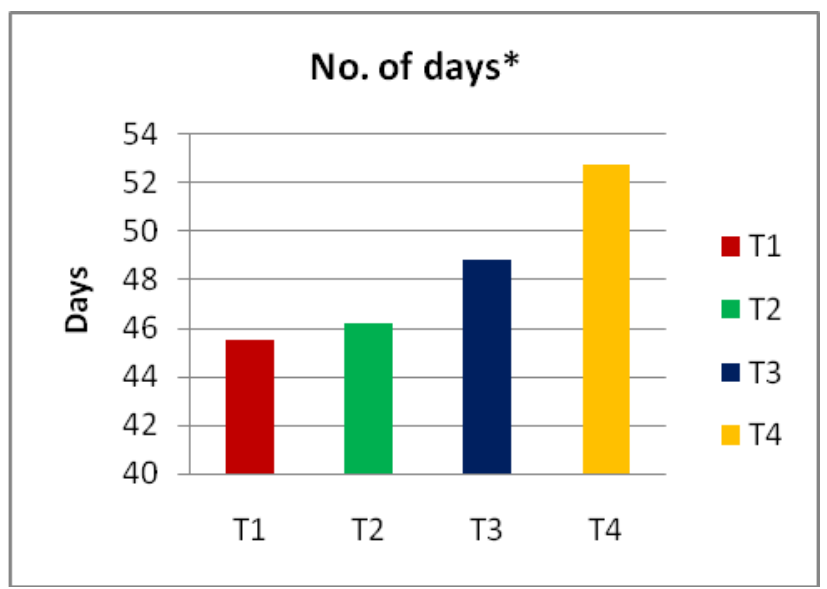

Fig.2

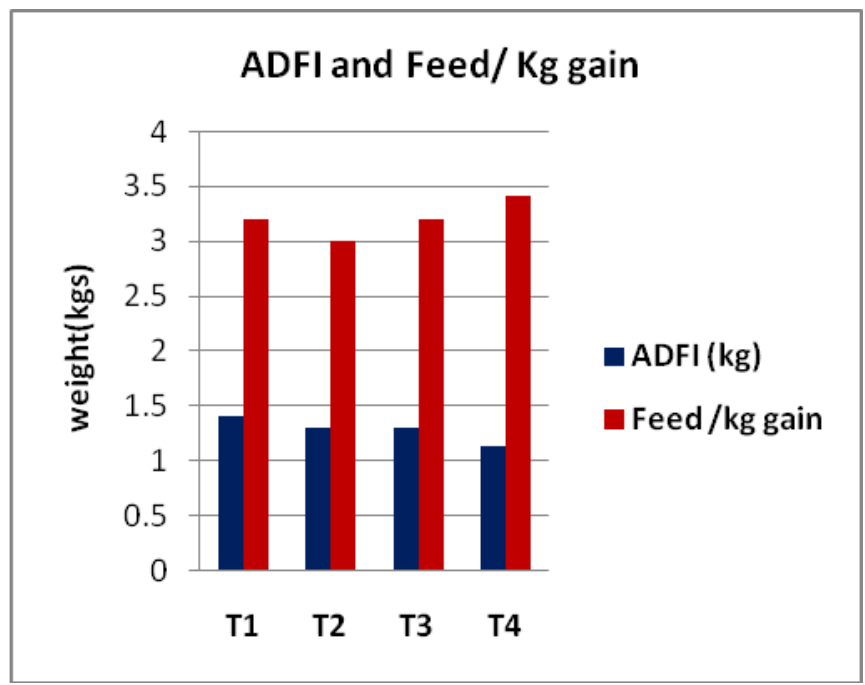

Fig.3 
Int.J.Curr.Microbiol.App.Sci (2020) 9(3): 418-428

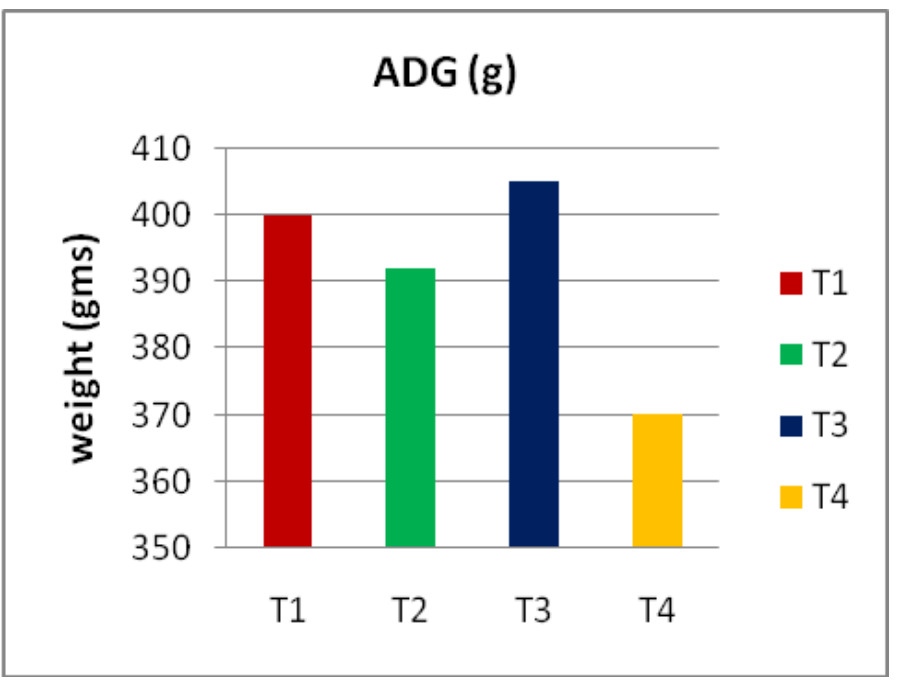

Fig.4

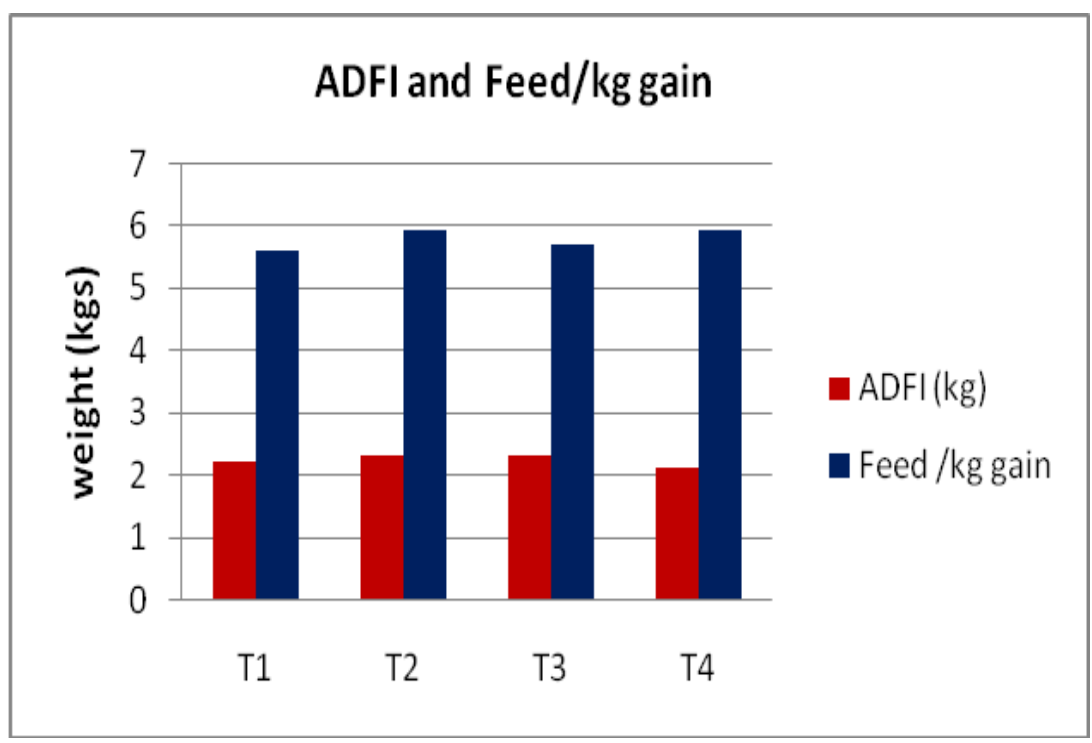

Fig.5

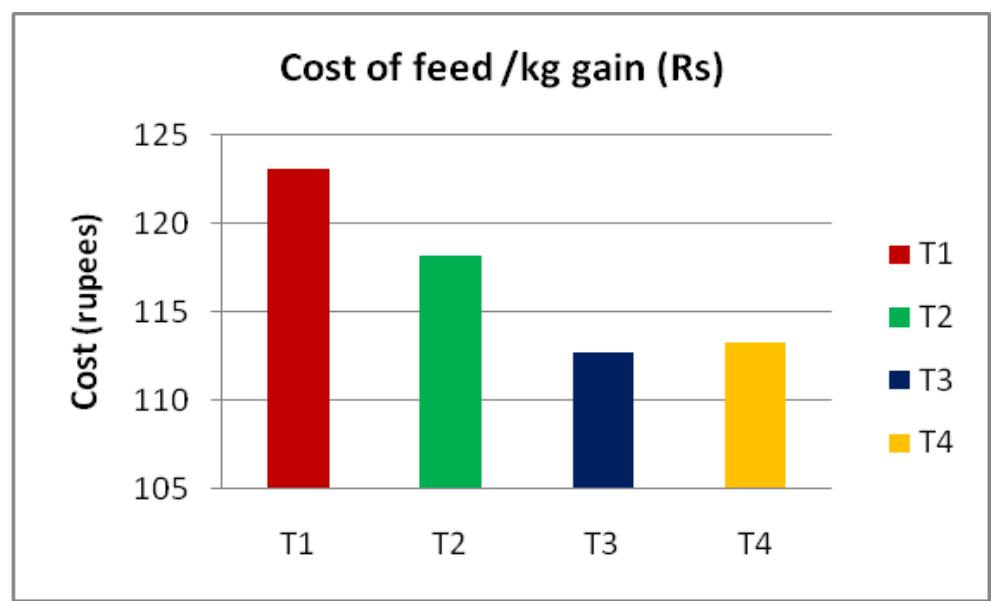

Fig.6 
A continuous effort is needed to lower the cost of pig production as an economic measure. Use of rice DDGS as protein source in the diets of pig diets was found to be effective. It was concluded that contributing (\%) 20 and 30 of the CP through DDGS improved ADG and reduced the cost of feed gain per $\mathrm{kg}$ gain in growers and finishers, respectively. However, long term trials need to be studied to record the ill effects.

\section{References}

Chatterjee A, Dey D, Mandal D K, Mohammad A and Bhakat C 2016. Utilization of Rice Dried Distillery Grain with Soluble as Feed for Ruminants. International Conference on Agriculture, Food Science, Natural Resource Management and Environmental Dynamics: 74-77.

Cook D, N Paton and M Gibson 2005. Effect of dietary level of distillers dried grains with solubles (DDGS) on growth performance, mortality, and carcass characteristics of grow-finish barrows and gilts. Journal of animal science 83(1):335.

De Matteis M C, Yu T E, Boyer C N, DeLong K L and Smith J 2018. Economic and environmental implications of incorporating distillers' dried grains with solubles in feed rations of growing and finishing swine in Argentina. International Food and Agribusiness Management Review. 21(6): 803-816.

DeDecker, J M, Ellis M, Wolter B F, Spencer J, Webel D M, Bertelsen C M and Peterson B A 2005. Effects of dietary level of distillers dried grains with solubles and fat on the growth performance of growing pigs Journal of animal science. 83(2): 79.

Feoli C 2008; Use of corn- and sorghumbased distillers dried grains with solubles in diets for nursery and finishing pigs.
Ph.D. thesis, Kansas State University, Manhattan, Kansas, USA.

Gaines A M, Petersen G I, Spencer J D, and Augspurger N R 2007. Use of corn distillers dried grains with solubles (DDGS) in finishing pigs. Journal of animal science. 85(2): 55.

India Brand Equity Foundation (IBEF), 2018. An initiative of the Ministry of Commerce \& Industry, Government of India.

Website:

https://www.ibef.org/news/foodgrainproduction-at-record-27951-mt-in201718-govt

Jaishankar S, Murugan M and Gopi H 2015. Comparative pre-weaning performance of $75 \%$ Large White Yorkshire crossbred pigs of fifth and sixth filial generation. International Journal of Science, Environment and Technology. 4(4): 1236 - 1239.

Linneen S K, DeRouchey J M, Dritz S S, Goodband R D, Tokach M D and Nelssen J L 2008. Effects of dried distiller's grains with solubles on growing and finishing pig performance in a commercial environment, Journal of Animal Science. 86(7): 1579-1587.

Liu K 2011. Chemical composition of distillers grains, a review. Journal of Agricultural and Food Chemistry. 59(5): 1508-1526.

NRC 2012. Nutrient Requirements of Swine. 11 th ed. NRC Press.

Stein Hans and De Lange Kees 2007. Alternative feed ingredients for pigs. London Swine Conference - Today ${ }^{e e}$ s Challenges Tomorrowees Opportunities. 3(4): 103-117.

Thacker P A 2006. Nutrient digestibility, performance and carcass traits of growing finishing pigs fed diets containing dried wheat distiller's grains with solubles. Canadian Journal of Animal Science. 86: 527-529.

Whitney M H, Shurson G C, Johnston L J, 
Wulf D M and Shanks B C 2006. Growth performance and carcass characteristics of grower-finisher pigs fed high-quality corn distillers dried grain with solubles originating from a modern midwestern ethanol plant. Journal of Animal Science. 84: 33563363.

Widyaratne G P and Zijlstra R T 2007.
Nutritional value of wheat and corn distillers dried grain with solubles: digestibility and digestible contents of energy, amino acids and phosphorus, nutrient excretion and growth performance of growerfinisher pigs. Canadian Journal of animal Science. 87: 103-114.

\section{How to cite this article:}

Siva Reddy. A. V, MVAN. Suryanarayana, A. Ravi, G. Ganga Raju and Suresh Babu. D. 2020. Effect of Inclusion of Rice DDGS on the Performance in Crossbred Pigs. Int.J.Curr.Microbiol.App.Sci. 9(03): 418-428. doi: https://doi.org/10.20546/ijcmas.2020.903.049 